\title{
SIMILARIDADE GENÉTICA DE VARIEDADES CRIOULAS DE ARROZ, EM FUNÇÃO DA MORFOLOGIA, MARCADORES RAPD E ACÚMULO DE PROTEÍNA NOS GRÃOS ${ }^{(1)}$
}

\author{
ROGERIA GREGIO DE BIASE MARTINS AREIAS ${ }^{(2)}$; DIOGO MENDES DE PAIVA ${ }^{(3)}$; \\ SONIA REGINA SOUZA ${ }^{(4)}$; MANLIO SILVESTRE FERNANDES ${ }^{(5)}$
}

\begin{abstract}
RESUMO
Em experimentos em casa de vegetação e câmara de crescimento, estudou-se o possível aparecimento de réplicas em 20 variedades crioulas de arroz do Maranhão, mantidas no Banco Ativo de Germoplasma (BAG), do Centro Nacional de Pesquisa em Arroz e Feijão (CNPAF). As vinte variedades, divididas em seis grupos, com nomes similares e números de acessos diferentes no BAG foram avaliadas quanto à similaridade morfológica e molecular. As características morfológicas foram avaliadas e utilizadas para a construção de um dendrograma de similaridade. Após a colheita determinou-se o teor de proteína bruta dos grãos. No experimento em câmara de crescimento além das vinte variedades, utilizou-se a cultivar melhorada (IAC47). O DNA da parte aérea dessas plantas foi amplificado pela técnica do RAPD (DNA Polimórfico Amplificado ao Acaso), para se avaliar a similaridade genética entre as variedades. $\mathrm{O}$ dendrograma utilizando as características morfológicas revelou dois grupos, sendo um formado pelas plantas de nome "Lageado" e outro com as demais variedades. A análise genética confirmou os dados de morfologia, separando o grupo "Lageado" (com mais de $70 \%$ de similaridade) das demais variedades, que formaram um grupo com dois subgrupos. Em um dos subgrupos, agruparam as variedades com maiores teores de proteína bruta nos grãos, confirmando a alta diversidade das variedades estudadas. Os resultados revelaram que algumas plantas de nome semelhante e número de acesso distinto são provavelmente a mesma variedade, e as plantas de nome "Lageado" formam um grupo à parte, cujas características, inclusive produtividade, merecem maiores estudos.
\end{abstract}

Palavras-chave: similaridade genética, características morfológicos, RAPD, proteína bruta dos grãos.

\section{ABSTRACT \\ GENETIC SIMILARITIES OF RICE LANDRACES ACCORDING TO MORPHOLOGY, RAPD MARKERS AND GRAIN PROTEIN CONTENT}

Twenty rice landraces from Centro Nacional de Pesquisa em Arroz e Feijão (CNPAF), Brazil, were studied as to morphological traits, DNA markers revealed by RAPD technique and protein content. Assessed landraces were different Active Germplasm Bank (AGB) accessions comprising six groups of same common names. Similarity dendrograms based on morphological traits and DNA markers, revealed two groups, one of them, with $70 \%$ similarity, includes all accessions that had the term 'Lageado' in its common name. Dendrogram based on DNA markers further split the second group into two groups with different protein content. The results indicated that, in some cases, different accessions may actually represent the same germplasm. The "Lageado" group deserves more detailed investigations due to its favorable agronomic characteristics and high yield.

Key words: Genetic divergence, germplasm, Oryza sativa.

$\left.{ }^{1}{ }^{1}\right)$ Recebido para publicação em $1 .^{\circ}$ de fevereiro e aceito em 16 de dezembro de 2005.

$\left(^{2}\right)$ Mestre em Agronomia.

$\left({ }^{3}\right)$ Estudante de Agronomia, bolsista do PIBIC.

$\left({ }^{4}\right)$ Departamento de Química, Universidade Federal Rural do Rio de Janeiro, Rodovia Rio-São Paulo, km 47, 23890-000 Seropédica (RJ). E.mail: soniabq@ufrrj.br

$\left(^{5}\right)$ Departamento de Solos, UFRRJ, Seropédica (RJ), Brasil. E.mail: manlio@ufrrj.br 


\section{INTRODUÇÃO}

O arroz é o segundo cereal mais consumido no mundo, atendendo à grande parte da necessidade protéica e calórica da população mundial. Excetuando os países asiáticos, o Brasil é o primeiro produtor mundial, mas ocupa a $46 .^{a}$ posição em rendimento e a 10. ${ }^{a}$ posição entre os países da América do Sul, onde o mais alto rendimento médio, obtido no Uruguai $\left(6.771 \mathrm{~kg} \mathrm{ha}^{-1}\right)$, foi o dobro do rendimento médio brasileiro de $3.552 \mathrm{~kg} \mathrm{ha}^{-1}$, na safra de 2004 (FAO, 2005).

O Estado do Maranhão é o segundo maior produtor de arroz com 742.000 toneladas (safra 1999/ 2000), sendo a produção obtida quase na sua totalidade por variedades cultivadas no sistema de terras altas (sequeiro) (AgRiAnUAL, 2001). No Maranhão verifica-se o maior número de variedades tradicionais de arroz do País (FonseCA et al., 1982), conservadas por pequenos agricultores que, sem recursos financeiros, utilizam técnicas de cultivo com pouca aplicação de fertilizantes. Esses germoplasmas tradicionais, com sua grande variabilidade genética, constituem fontes de genes de inestimável valor para os programas de melhoramento de arroz no País (FonsECA et al., 1982).

Como a base genética das variedades melhoradas de arroz de terras altas cultivadas na América Latina e no Brasil, é relativamente estreita (GUIMARÃES et al., 1996), torna-se importante o estudo das variedades tradicionais, a fim de obter mecanismos de tolerância a estresses ambientais (como déficit hídrico e $\mathrm{Al}^{+3}$ ) e possivelmente de eficiência de uso de nutrientes (SouzA et al., 1998).

Nos países do terceiro mundo, do total da área cultivada com trigo, arroz e milho, estima-se que 50\% estejam ocupadas com variedades locais (CLEVELAND et al., 1994).

A coleção ativa de arroz no Brasil é mantida no BAG da Embrapa Arroz e Feijão, Goiânia (GO), que mantém acessos com ampla variabilidade genética, visando à preservação e multiplicação em curto prazo, em quantidades suficientes para atender as solicitações. A ampliação é feita através da introdução e doação espontânea de germoplasma, fazendo-se necessária sua multiplicação, pois o tamanho das amostras recebidas é geralmente pequeno (GIACOMETTI e Fonseca, 1980). Além disso, os acessos são caracterizados morfologicamente, utilizando uma lista de descritores mínimos considerados preliminares (Fonseca, 1982).

Na coleção ativa, desde 1975 até 2000, foram registrados 9.924 acessos de arroz, sendo $56 \%$ de acessos nacionais (5.583) e $44 \%$ do exterior (4.341) (Silva et al., 2001).

Os acessos extras de algum genótipo ou material muito idêntico denominam-se duplicatas, que são variantes de uma mesma variedade (SILVA, 1999). Essas duplicidades surgem quando uma variedade se expande e é cultivada em muitos locais, originando nomes diferentes dados pelos produtores. Os acessos em duplicatas podem ser identificados pelo emprego de técnicas que envolvem o uso de marcadores isoenzimáticos, principalmente, os moleculares usando os procedimentos como as técnicas de RFLP (Polimorfismo no Comprimento de Fragmento de Restrição) e RAPD (Amplificação Randômica do DNA Polimórfico). Outra opção é o uso das técnicas multivariadas, pois através de algumas delas é possível avaliar a divergência entre as espécies e, conseqüentemente, identificar amostras repetidas (RANGel et al., 1991; FonSECA et al., 1995).

A técnica do DNA polimórfico amplificado ao acaso (RAPD), constitui-se em uma variação da técnica de PCR (reação da polimerase em cadeia). A análise genética com marcadores RAPD é uma técnica simples e rápida, que permite verificar a baixo custo, a existência de polimorfismo e detectar diferenças genéticas entre e dentro das espécies. Nos últimos anos, mapas filogenéticos têm sido construídos utilizando a técnica de RAPD em arroz (BAPTISTA, 2002; ARAúJO et al., 2003).

A avaliação fenotípica é realizada por meio de comparações de características morfológicas dos indivíduos, como as cores das flores e sementes, cor e tipo de pubescência, dentre outras. Como esses parâmetros podem ser afetados pelas condições ambientais (SINGH et al., 1996; KAW, 1995), neste trabalho se propõe a comparação das características baseadas no fenótipo com a avaliação direta do genótipo, usando marcadores moleculares, que detectam o polimorfismo na seqüência de nucleotídeos no DNA (WAugh et al., 1992; Souza e Souvelis, 1989).

\section{MATERIAL E MÉTODOS}

Foram desenvolvidos dois experimentos em casa de vegetação no Departamento de Solos da Universidade Federal Rural do Rio de Janeiro (UFRRJ), RJ, localizado a $22^{\circ} 45^{\prime}$ de latitude Sul e $43^{\circ} 41^{\prime}$ de longitude Oeste, com o cultivo de vinte variedades tradicionais de arroz do Estado do Maranhão. O primeiro experimento foi instalado no início de agosto de 2002, com colheita final em março de 2003 (Período I). O plantio do segundo experimento foi em novembro de 2003 e a colheita final em junho de 2003 (Período II). 
As sementes das variedades de arroz foram oriundas do Banco Ativo de Germoplasma de Arroz (BAG - Arroz) da Embrapa Arroz e Feijão, Santo Antônio de Goiás (GO) e de coletas realizadas em regiões produtoras do Estado do Maranhão. A escolha dos acessos foi feita com base em estudos realizados por ARAújo et al. (2003), que usou treze delas e por FERraz Junior et al. (2001), que trabalhou com sete variedades.

Como substrato para o crescimento das plantas utilizou-se terra proveniente do horizonte Ap (0-20 cm) de Argissolo Vermelho-Amarelo de ocorrência no Rio de Janeiro.

De acordo com a análise química do solo (EMBrapa, 1979) foi feita uma adubação no plantio e outra em cobertura no período de formação de panículas (emborrachamento) com $40 \mathrm{~kg} \mathrm{ha}^{-1}$ de $\mathrm{N}$ na forma de uréia, $30 \mathrm{~kg} \mathrm{ha}^{-1}$ de $\mathrm{K}_{2} \mathrm{O}$ e $10 \mathrm{~kg} \mathrm{ha}^{-1}$ de $\mathrm{P}_{2} \mathrm{O}_{5}$, como recomendado para a cultura do arroz no Estado do Rio de Janeiro (Oliveira e TeIXeIRA, 1988), não tendo sido utilizado fosfato na adubação de cobertura.

Em vasos de plásticos que receberam $7 \mathrm{~kg}$ de terra peneirada, foram semeadas 10 sementes. Dez dias após a emergência foi feito um desbaste deixando-se duas plântulas por vaso. O delineamento experimental foi em blocos ao acaso, com 20 variedades em três repetições. A temperatura e a umidade relativa do ar foram registradas diariamente em termo-higrógrafo.

As características morfológicas das variedades de arroz (datas de emergência e floração; ciclo cultural; comprimento médio da planta; ângulo da folha bandeira; cores das folhas, do colar, da lígula, da aurícula e do apículo na floração; comprimento e largura da folha bandeira; número de panículas e perfilhos; exerção e comprimento da panícula) foram avaliadas nos estádios de plântulas, floração, maturação e por ocasião da colheita e pós-colheita, de acordo com FONSECA et al. (1982 e 1984) e BRASIL (1997). Após a colheita, as panículas e os grãos foram pesados e medidos. Vinte grãos foram descascados à mão e moídos, a farinha passada em almofariz e amostras de $200 \mathrm{mg}$ dessa farinha de arroz foram digeridas com ácido sulfúrico e água oxigenada. Após a destilação do material digerido obteve-se o N-total (Tedesco et al., 1995). O conteúdo de proteína bruta dos grãos foi calculado multiplicando-se o teor de Ntotal pelo fator 5,95, com base no conteúdo de nitrogênio $(16,8 \%)$ da principal proteína do arroz, a glutelina (Juliano, 1985).

Para avaliação da similaridade genética, usando o método de RAPD, proposto por WiLLiams et al. (1990), foi feito um experimento em câmara de crescimento utilizando-se as 20 variedades do experimento em casa de vegetação, acrescida da variedade melhorada (IAC 47). As sementes de arroz foram primeiramente esterilizadas em solução $5 \%$ de hipoclorito de sódio, lavadas e germinadas em placas de Petri contendo água destilada. Após a germinação, as plântulas com idade de 5 dias, foram transferidas para potes contendo solução nutritiva de FurLani e Hanna (1984) a meia força iônica, e colocadas em câmara de crescimento $\left(21{ }^{\circ} \mathrm{C}\right.$ e $70 \%$ de umidade relativa) sendo trocada a solução após cinco dias para uma força iônica.

A extração de DNA para análise da similaridade genética foi feita segundo procedimentos de MAC Couch et al. (1988). A quantidade de DNA foi estimada pela relação $260 / 280$, em que cada unidade de absorvância correspondeu a $40 \mu \mathrm{g} / \mathrm{ml}$ de DNA de fita simples (SАмвRоOK et al., 1989), também foi feita a quantificação pela comparação com concentrações conhecidas de DNA em gel de agarose a $1 \%$. As amostras utilizadas no RAPD, após a quantificação total, partiram de diluições da amostra total em água estéril, contendo $5 \mathrm{ng} / \mu \mathrm{l}$ de DNA. As alíquotas foram armazenadas a $-20{ }^{\circ} \mathrm{C}$.

Os iniciadores utilizados foram: OPA 3, OPA 4, OPA10 e OPA 18, previamente selecionados por Araújo (2002) e OPA 2 e OPA 20 selecionados por Silva (1999), todos da Operon Technologies, Kit A.

As reações foram desenvolvidas, de acordo com protocolo de (Williams et al., 1990), com modificações (ARAúJo, 2002), de maneira que o volume final de $16 \mu$ l continha 1,2 x de Tampão $10 \times$ (Kit Promega), 2,3 mM MgCl 2 , 0,2 Mm de cada dNTP, 0,2 $\mu \mathrm{m}$ do iniciador, $3 \mathrm{mg} / \mu \mathrm{L}$ de BSA, 1,0 unidade Taq polimerase, $20 \mathrm{ng}$ de DNA molde, completando o volume final com água ultrapura. Para cada reação, foi feita uma reação sem o DNA (substituído por água) para certificar de que não houve contaminação. Para as amplificações, foram realizados 45 ciclos de $94{ }^{\circ} \mathrm{C}$ por 5 minutos (desnaturação inicial) seguidos de 35 ${ }^{\circ} \mathrm{C}$ durante 1 minuto (anelamento), 30 segundos a 94 ${ }^{\circ} \mathrm{C}$ (desnaturação), $72{ }^{\circ} \mathrm{C}$ durante 2 minutos (extensão), após os 45 ciclos, a extensão da fita foi efetuada a 72 ${ }^{\circ} \mathrm{C}$ por 5 minutos (termociclador marca Eppendorf). Para a separação dos produtos amplificados, utilizouse eletroforese horizontal, em gel de agarose $1,5 \%$, corado com brometo de etídeo $1 \mathrm{mg} / \mathrm{mL}$. Utilizaramse $10 \mu \mathrm{l}$ de cada reação, acrescido de $2 \mathrm{~mL}$ de uma solução de azul de bromofenol (40\%), mais sacarose. Foi utilizado TBE 0,5x, como tampão do gel e da corrida, que durou 2 horas com voltagem de $100 \mathrm{~V}$. Após a eletroforese, os géis foram visualizados e fotografados utilizando câmara Polaróide. 
Para o agrupamento dos caracteres morfológicos foi utilizada a Distância Euclidiana. Para a análise da similaridade genética, as bandas de DNA obtidas no gel com base no método RAPD foram transformadas em matriz binária (um para presença da banda e 0 para ausência da banda no gel) e o resultado dessas análises foi executado em software NTSYS (RoHLF, 2001). As análises necessárias para a construção dos dendrogramas foram efetuadas segundo o método da média aritmética não ponderada (UPGMA) e o agrupamento seqüencial, aglomerativo, hieráquico e exclusivo (SAHN).

\section{RESULTADOS E DISCUSSÃO}

No dendrograma de similaridade de características morfológicas das plantas de arroz formaram-se dois grupos, sendo um composto pelas plantas de nome "Lageado" e outro com as demais variedades (Figura 1). A análise genética confirmou os dados de morfologia, por haver separado também as variedades em dois grupos: um com as variedades de nome "Lageado" (grupo 1) (com mais de $70 \%$ de similaridade entre si), e outro (grupo 2) com as demais variedades (Figura 2).
O agrupamento 2 do dendrograma de similaridade genética pode ser subdividido em subgrupos 2.1 e 2.2 (Figura 2). Dos três acessos com o nome Pingo D'água, dois agrupam no bloco 2.1, enquanto o terceiro agrupa no bloco 2.2. Esse último (220019) teve maior ciclo e floração mais tardia (Tabela 1), tendo ao contrário dos dois outros acessos, aumento na data de floração no período II. A variedade Pingo D'água, acesso 220019, também difere dos outros de mesmo nome quanto à massa de grãos por vaso e massa de mil grãos que são inferiores aos demais (Períodos I e II) (Tabela 2).

No subgrupo 2.2 (Figura 2), destaca-se o agrupamento $2.2 \mathrm{a}$, com $94 \%$ de similaridade, no qual se notam variedades com maiores teores de proteína bruta no grão (10,85\% e $11,23 \%$, para os períodos I e II, respectivamente) e baixa relação comprimento/ largura $(1,64$ e 1,80) para os períodos I e II, respectivamente (Tabela 2 ).

As variedades Bacabinha (220027 e 210057) possuem $97 \%$ de similaridade genética; o mesmo ocorre entre as variedades Zebu (790028) e Jatobá (220012), que devido ao alto grau de semelhança podem ser consideradas como a mesma variedade (Figura 2).

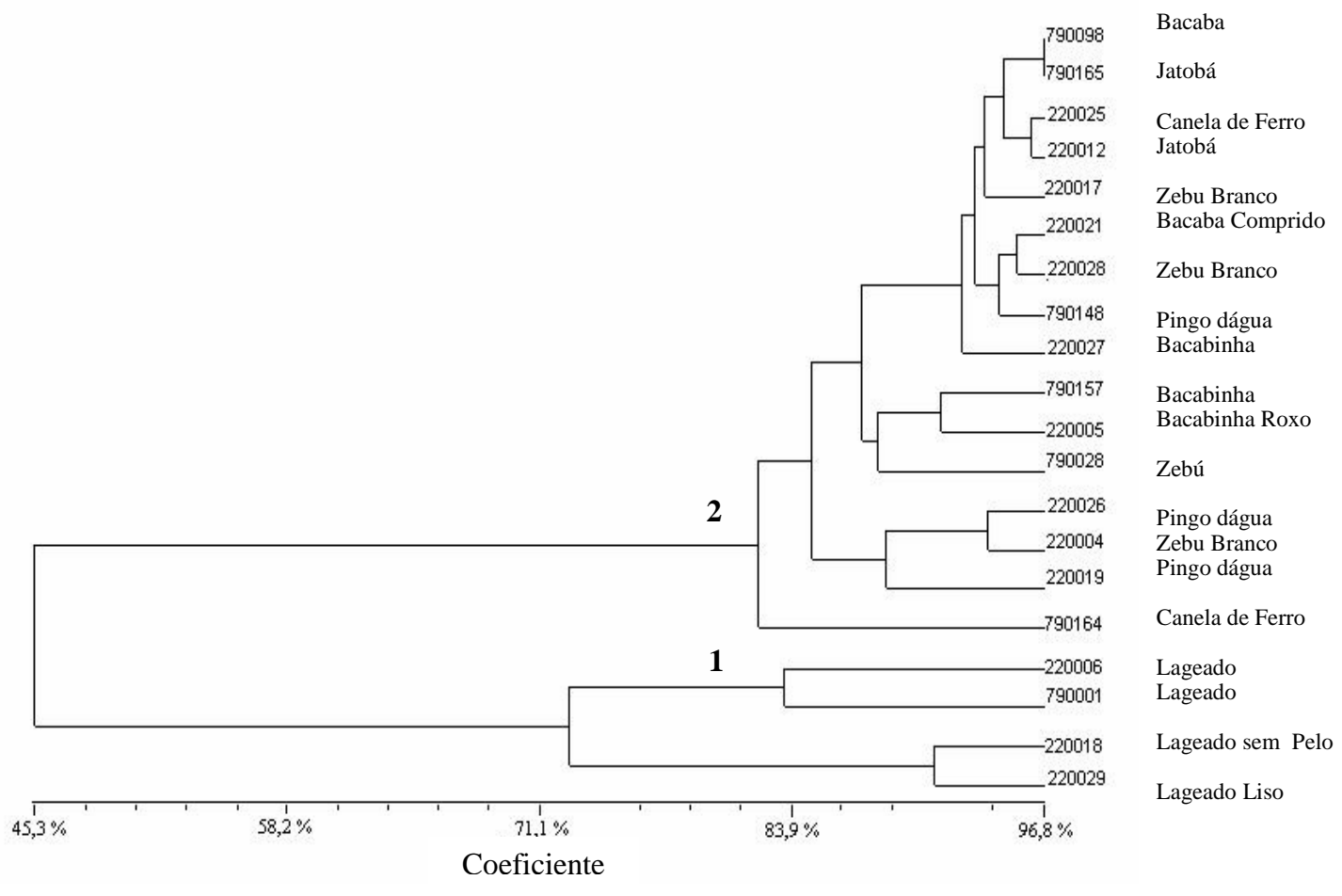

Figura 1. Dendrograma obtido a partir das características morfológicas de 20 variedades locais de arroz do Estado do Maranhão 


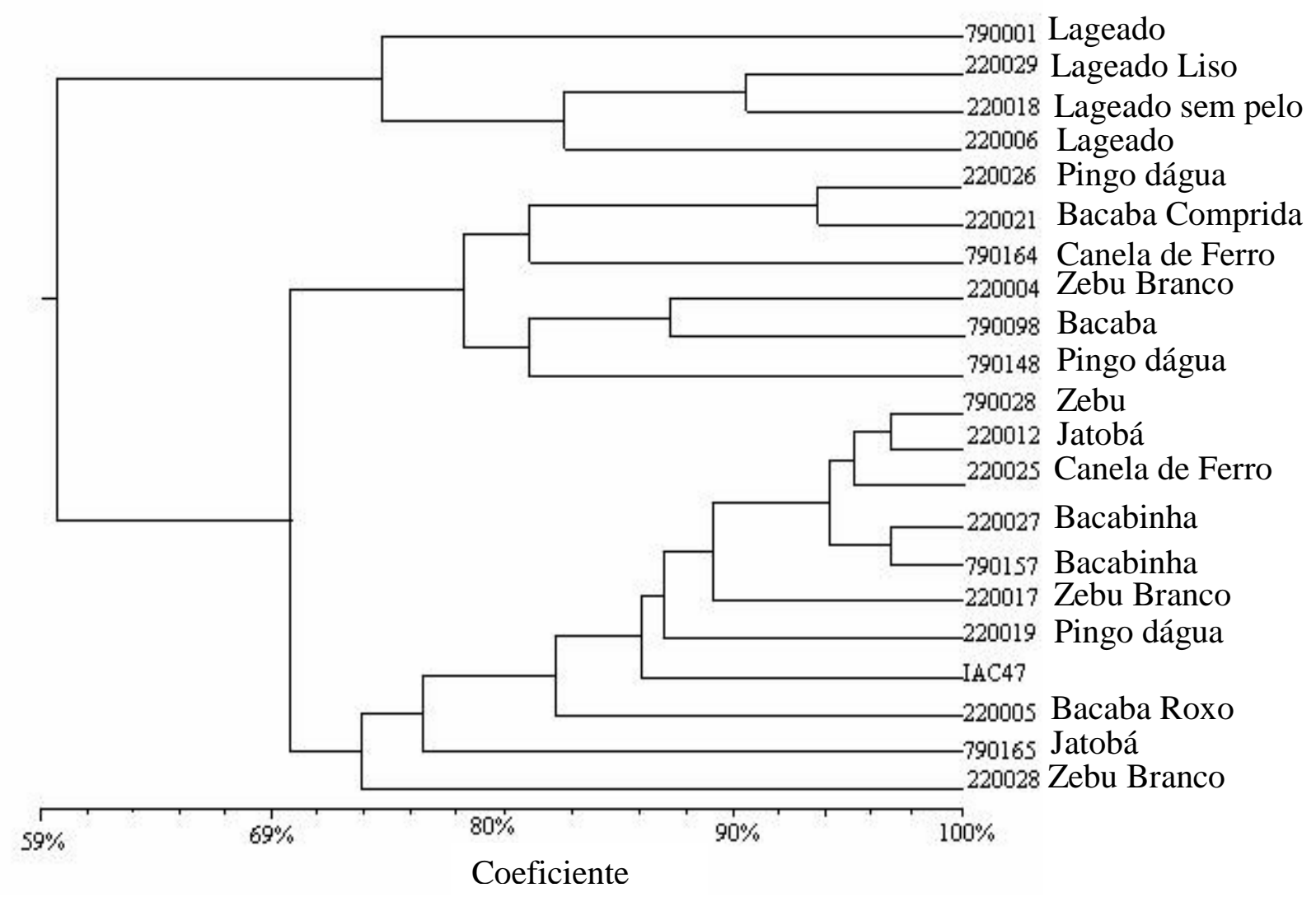

Figura 2. Dendrograma de similaridade genética a partir dos fragmentos de DNA amplificados ao acaso (RAPD) de 20 variedades crioulas de arroz do Maranhão e da variedade melhorada IAC-47.

As variedades com o nome "Lageado" (quatro acessos) formam um grupo à parte (grupo 1), tanto pelas características morfológicas como pelas genéticas (Figuras 1 e 2). As plantas com os nomes de "Lageado liso" e "Lageado sem pêlo" são muito próximas, com mais de $90 \%$ tanto de similaridade genética, como também de similaridade morfológica, sendo possivelmente as mesmas variedades, cadastradas com números de acessos diferentes (220029 e 220018). Essas plantas têm ainda a característica única de ao acamar, formar um apoio no último nó da haste que sustenta a panícula, mantendo-a em média a $30 \mathrm{~cm}$ de altura do solo.

As variedades "Lageado" caracterizam-se pelo ciclo longo (215 dias, contra 171 da média das 20 outras variedades) e também pela floração mais tardia (Tabela 1). Como um grupo, nas variedades "Lageado" houve grande restrição na produção de grãos Período I, marcando um grande contraste com a produção obtida no Período II. Do ponto de vista de produção de grãos por vaso, as variedades "Lageado" foram as mais afetadas pela variação de comprimento do dia entre os períodos I e II. Observamse, no grupo de variedades "Lageado", os menores teores de proteína bruta do grão no período I (média de $6,78 \%$ contra 9,61 do conjunto das 20 variedades). Esse grupo de plantas também tem a maior relação comprimento/largura (2,94 contra 2,13 do conjunto). Em relação aos teores de proteína bruta, as variedades "Lageado liso e sem pêlo" também divergem das outras duas (Tabela 2). É interessante observar que foi encontrada uma correlação negativa $\left(-0,599^{* *}\right)$ entre a relação comprimento largura e o teor de proteína bruta nos grãos, com o conjunto de variedades, confirmando os resultados de ARAújo et al. (2003), em que os maiores teores de proteína estão presentes nas variedades com grãos mais arredondados.

As duas variedades com o nome "Canela de ferro" estão em dois agrupamentos distintos tanto no dendrograma de similaridade genética quanto no de características morfológicas (Figuras 1 e 2). Não são observadas grandes divergências entre esses dois acessos no que se refere aos aspectos vegetativos (Tabela 1). Quanto à fase reprodutiva, observa-se diferença em relação à massa de grãos por vaso, tendo o acesso 220025 menores valores. Para o teor de proteína bruta ocorre uma inversão de valores para os dois acessos nos períodos de cultivo I e II (Tabela 2). 


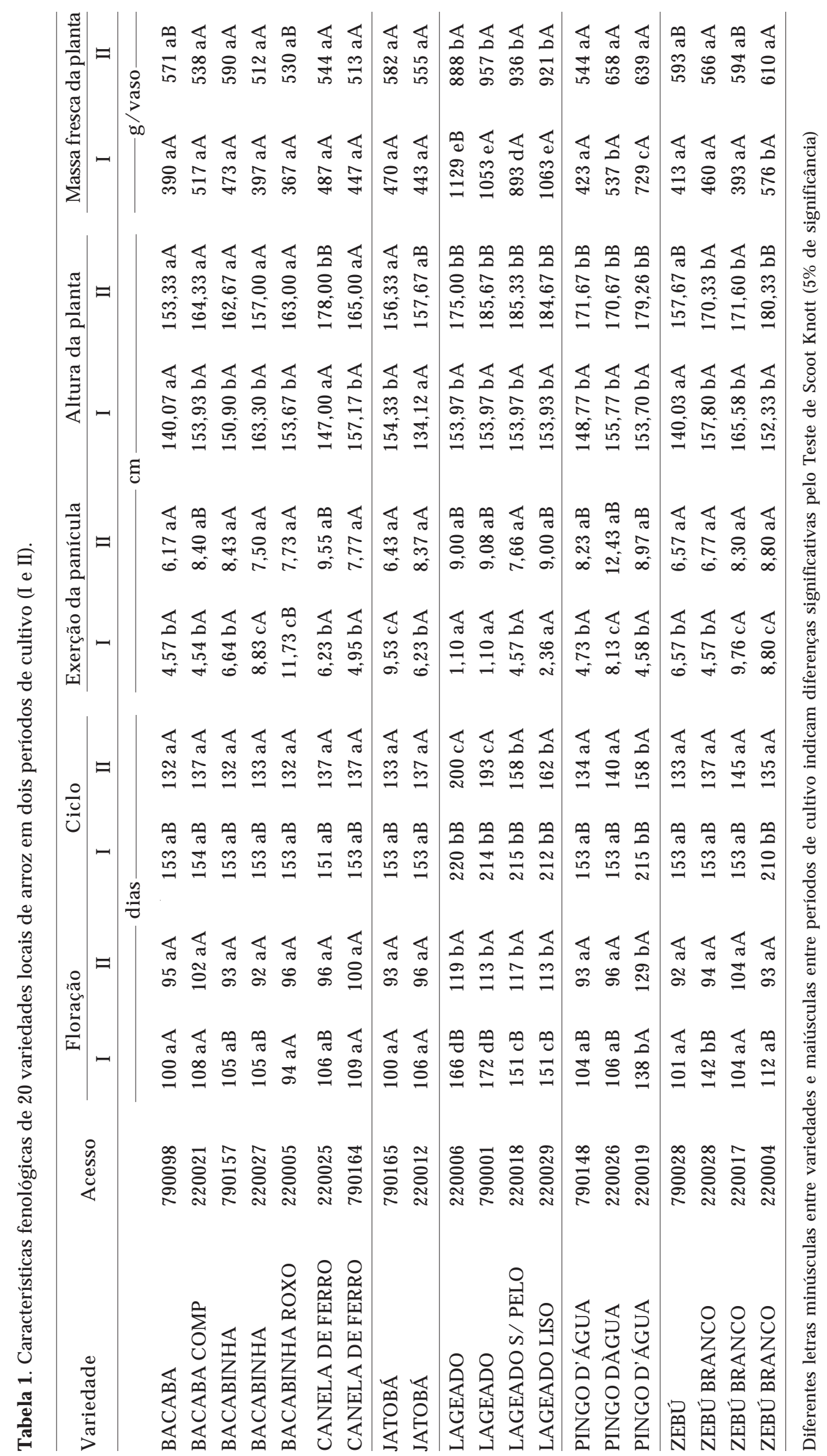




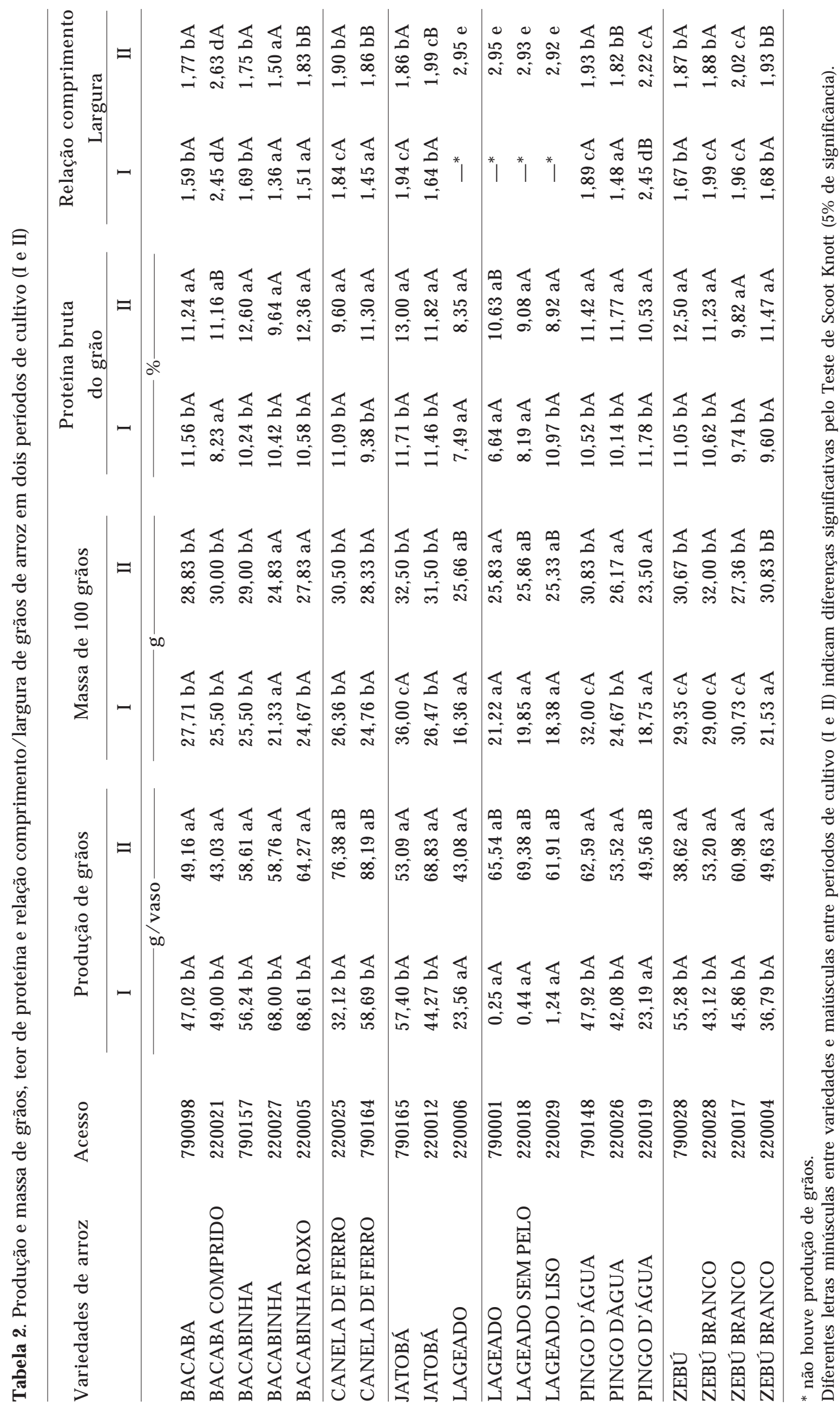


As duas variedades de nome Jatobá aparecem no agrupamento $2.2 \mathrm{com} 75 \%$ de similaridade genética (Figura 2) e mais de $90 \%$ de similaridade morfológica (Figura 1). Essas variedades não possuem grande diferença quanto aos aspectos fenológicos (Tabela 1). Surgem diferenças, entretanto, quanto à massa de grãos por vaso, ao teor de proteína bruta do grão e na relação comprimento largura no período I (Tabela 2); o acesso 250165 tem os maiores valores de proteína do grão no período II (13,38 contra a média de 11,05 do conjunto de variedades). As variedades Jatobá (220012) e Zebú (790028), com 97\% de similaridade genética, fazem parte do agrupamento 2.2a (Figura 2).

No grupo Bacaba e Bacabinha, duas variedades (Bacaba e Bacaba comprido) estão no grupo 2.1 do dendrograma de características genéticas (Figura 2). As variedades Bacabinha estão no grupo 2.2a com $97 \%$ de similaridade genética, e ao se incluir a variedade Bacabinha roxo, a similaridade entre elas passa para $82 \%$. As variedades Bacabinha e Bacabinha roxo foram as de maior massa de grãos por vaso, tanto no período de cultivo I como no período II (Tabela 2). A variedade Bacaba comprido, excepcionalmente, com valor muito baixo de proteína bruta nos grãos no período I $(5,49)$, e também elevada relação $\mathrm{C} / \mathrm{L}(2,63)$, foi uma exceção nesse grupo de plantas. Essa variedade também apresentou menor massa de grãos por vaso e menor massa de mil grãos no período I (Tabela 2).

Duas das variedades denominadas "Zebu branco" estão no grupo 2.2, enquanto a outra (22004) está no grupo 2.1, geneticamente distante das outras. A variedade Zebu está no grupo 2.2a, de alto teor de proteína bruta no grão (Figura 2). A variedade Zebu branco foi a mais afetada pelo fotoperíodo, no período I, com menor massa de grãos por vaso e menor massa de mil grãos. A variedade Zebu branco (CA 220004) teve a maior altura entre todas as variedades no período II. Essa variedade também teve a maior massa fresca total entre as variedades de nome Zebu (Tabela 2).

Os teores de proteína bruta dos grãos obtidos neste trabalho são superiores aos verificados por Araújo et al. (2003). Comparando-se as médias das 12 variedades comuns em ambos os trabalhos: "Lageado sem pêlo" (220018), "Pingo d'água" (220019), "Canela de ferro" (220025), "Zebu branco" (220004), "Bacabinha roxo" (220005), "Lageado" (220006), "Bacaba comprido" (220021), "Pingo d'água" (220026), "Bacabinha" (220027), "Zebu branco" (220028), "Lageado liso" (220029), "Zebu branco" (220017) obtém-se 7,33\% de proteína bruta em ARAújO et al. (2003), contra $9,94 \%$ no período I e $10,43 \%$ no período II neste trabalho. É possível que os teores mais elevados de proteína bruta verificados neste trabalho possam ser atribuídos ao tipo de solo usado (Argissolo Vermelho-Amarelo) e à adubação nitrogenada suplementar na antese, como também observado em trabalho com arroz de Souza et al. (1998).

Quando se avalia a exerção da panícula, um parâmetro que pode indicar o estresse ao qual a cultura foi submetida, observa-se que no período I a média das 20 variedades para a exerção da panícula foi de $6,90 \mathrm{~cm}$, enquanto no período II foi de $8,15 \mathrm{~cm}$ (Tabela 1). O grupo de variedades mais afetado pelo período de plantio (período I e período II) foi o Lageado, cuja exerção da panícula no primeiro período de plantio foi de 2,3 e no segundo período 8,7. As condições ambientais durante o cultivo dessas variedades no Rio de Janeiro foram caracterizadas por uma drástica redução no comprimento do dia entre maio e julho (média de 10,8 horas de luz) (fim do período II de cultivo do arroz) e aumento do fotoperíodo entre novembro e janeiro $(13,2$ horas de luz) (final do período I e início do período II de cultivo do arroz). Essas características afetam o período de insolação com grande variação mês a mês, segundo FERraz Júnior. et al. (2001). Esses resultados evidenciam que as plantas cultivadas no período I estavam submetidas a estresse (mudança no fotoperíodo), com exceção de algumas variedades como a Bacabinha (220027), Bacabinha roxo (220005), Jatobá (790165) e Zebu Branco (220017).

Neste experimento observa-se, por exemplo, que o período da emergência à floração é de 108 dias em média para as 20 variedades no período I de cultivo e de 98 dias no período II. Quando se consideram, entretanto, apenas as variedades de nome Lageado os valores são de 160 dias para o período I e 115 dias para o período II. Essa redução de 44 dias pode explicar a grande variação na produção de grãos e massa de grãos por vaso (Tabela 2) entre um período e outro para essas variedades. Observa-se, entretanto, que os baixos teores de proteína nos grãos e as altas relações comprimento/ largura mantém-se, semelhante ao que foi observado por FERRAZ JúnIOR. et al. (2001) e ArAújo et al. (2003). O fato notável, entretanto, é que com apenas duas exceções (Bacaba comprido e Lageado) não existem diferenças significativas nos teores de proteína bruta nos grãos nas duas épocas, sendo a média geral na época I de 10,07\% e na época II de 10,92\%. Aparentemente, variações das condições ambientais, que podem ser observadas entre as épocas de cultivo I e II não afetaram o teor de proteína no grão, embora exerçam profunda influência sobre a época de floração, ciclo de plantio e exerção da panícula. 


\section{CONCLUSÕES}

1. Pelas análises genéticas, observa-se que as variedades de arroz de nome Bacabinha, com 97\% de similaridade, devem ser uma mesma variedade. $\mathrm{O}$ mesmo ocorre para o grupo Zebu-Jatobá, que pode ser considerado como formado pelas mesmas plantas.

2. Este trabalho coloca em evidência o grupo de variedades de arroz de nome "Lageado", como completamente distinto de todas as outras variedades coletadas no Maranhão. As variedades "Lageado" divergem não apenas no "make-up" genético, como mostrado pela análise de DNA, mas também nas características morfológicas da parte vegetativa e dos grãos. As informações colhidas junto aos agricultores do Maranhão de que este grupo é altamente produtivo, podem estar relacionadas ao comportamento dos colmos, que, ao acamar mantém eretas as panículas, aproximadamente a $30 \mathrm{~cm}$ do solo. Esse grupo merece maior estudo principalmente no que se refere à sua adaptação ao Estado do Maranhão.

\section{AGRADECIMENTOS}

Ao CNPq e a Faperj pelas bolsas e apoio financeiro.

\section{REFERÊNCIAS}

AGRIANUAL 2001. Anuário da Agricultura Brasileira FND Consultoria e Comércio. São Paulo, 2001. 545p.

ARAÚJO, E. S. Diversidade genética e acúmulo de proteína de reserva em arroz da Baixada Maranhense-MA. 2002. 60p. Dissertação (Mestrado em Agronomia - Ciências do solo) Instituto de Agronomia, Universidade Federal Rural do Rio de Janeiro, Seropédica.

ARAÚJO, E. S.; SOUZA, S.R.; FERNANDES, M.S. Características morfológicas e moleculares e acúmulo de proteína em grãos de variedades de arroz do Maranhão. Pesquisa Agropecuária Brasileira, Brasília, v. 38, n. 11, p.1281-1288, 2003.

BAPTISTA, J.A. Cinética de Absorção de $\mathrm{NH}_{4}{ }^{+}$, Efluxo de Prótons e Partição de N em Arroz. 2002. 107p. Dissertação (Mestrado em Agronomia - Ciências do solo) - Instituto de Agronomia, Universidade Federal Rural do Rio de Janeiro, Seropédica, 2002.

BRASIL. Decreto $n^{\circ} 2.366$, de 5 de novembro de 1997. Regulamenta a lei $\mathrm{n}^{\circ}$ 9.456, de 25 de abril de 1997, que institui a Proteção de Cultivares, dispõe sobre o Serviço Nacional de Proteção de Cultivares - SNPC, e dá outras providências. Diário Oficial [da] República Federativa do Brasil, Brasília, n. 216, p. 25333-25354, 7 nov. 1997. Seção 1, Edição comum.
CLEVELAND, D.A.; SOLERI, D.; AND SMITH, S.E. Do Folk Crop Varieties Have a Role in Sustainable Agriculture? BioScience, Washington, 44:740-751, 1994.

DE DATTA, S.R., OBCEMEA, W.N., JANA, R.K. Protein content of rice grain as effected by nitrogen fertilizer and some triazines and substitutes ureas. Agronomy Journal, Madison, v.64, p.785-788, 1972.

EMBRAPA. Serviço Nacional de Levantamento e Conservação de Solos. Manual de Métodos e Análise de Solo. Rio de Janeiro: EMBRAPA-SNLCS, 1979. n.p.

FAO. Faostat Agriculture Data. Disponível em: http:/ / faostat.fao.org/faostat/collections Acesso em 18 de outubro de 2005.

FERRAZ JUNIOR. A.S.L.; SOUZA S.R.; STARK E.M.L.; FERNANDES M.S. Crude Protein in Rice Grown in Different Environmental Conditions. Physiology and Molecular Biology of Plants, New Delhi. v. 7, n.2, p.149-157, 2001.

FONSECA, J.R.; ANDRADE M.J.B.A.; RAMALHO M.A. P.; FERREIRA, F. D. Divergência genética em germoplasma de feijão (Phaseolus vulgaris L.) coletado no Sul de Minas Gerais. Ciência e Prática, Lavras, v.4, n.19, p.383-389. 1995.

FONSECA, J.R.; RANGEL, P.H.; BEDENDO, I.P.; SILVEIRA, P.M.; GUIMARÃES, E.P.; CORANDIN, L. Características botânicas e agronômicas de cultivares e raças regionais de arroz (Oryza sativa L.) coletadas no Estado do Maranhão. Goiânia: Embrapa-CNPAF-Cernagen, 1982. 42p. (Boletim de Pesquisa 1)

FONSECA, J.R.; RANGEL; P.H. BEDENDO, L.; SILVEIRA, P.M., GUIMARÃES, E.P.; CORANDIN, L. Características botânicas e agronômicas de acessos e raças regionais de arroz (Oryza sativa L.) coletadas no Estado do Maranhão. Goiânia: EMBRAPA-CNPAF/EMBRAPA-CENARGEM, 1984. 40p. (Boletim de Pesquisa 1)

FURLANI, P.R.; HANNA, R.B. Avaliação da tolerância de plantas de arroz e milho ao alumínio em solução nutritiva. Revista Brasileira de Ciência do Solo, Campinas, n.8, p.205208, 1984.

GIACOMETTI, D. C.; FONSECA, J. N. L. Introdução, intercâmbio e quarentena de pós-entrada de germoplasma. In: SIMPOSIO DE RECURSOS VEGETAIS, sessão 1, 1980, Brasília. Anais... Brasília: CENARGEM/ EMBRAPA, 1979. p 15-18.

GUIMARÃES, E.P.; BORRERO, J.; OSPINA-REY, Y. Genetic diversity of upland rice germplasm distributed in Latin América. Pesquisa Agropecuária Brasileira, Brasília, v.31, n.3, p.187-194, 1996.

JULIANO, B.O. Polysaccharides, proteins and lipids of rice. In: JULIANO, B.O. (Ed.). Rice: chemistry and technology. 2.ed. St. Paul: American Association of Cereal Chemists, 1985. p. 59-175.

KAW, R., N. Analysis of divergence insome cold-tolerant rices. Indian Journal of Genetics and Plant Breeding, New Delhi, v.55, n.1, p.84-89, 1995. 
MAC COUCH, S.R.; KOCHERT, G.; YU, Z.H.; WANG, Z. Y.; KHUSH, G. S. COFFMAN, W. R.; TANKSLEY, S.D. Molecular mapping of rice chromosomes. Theoretical and Applied Genetics, New York, v.76, p.815-826, 1988.

OLIVEIRA, A.B. e TEIXEIRA, M.G. Manual de Adubação e Calagem para o Estado do Rio de Janeiro. Itaguaí: Universidade Rural, 1988. 179p.

RANGEL, N.H.P.; CRUZ, D.C.; VENCOVSKY R.; FERREIRA, P.R. Selection of local lowland rice cultivars based on multivariate genetic divergence. Revista Brasileira de Genética, Ribeirão Preto v.14, n.2, p.437-453, 1991.

ROHLF, F. J. NTSYS-pc: Numerical taxonomy and multivariate analysis system. New York: Exeter software, 2001. 180 p.

SAMBROOK, J.; FRITSCH, E.F.; MANIATIS, T. Molecular cloning: Laboratory Manual. New York: Cold Spring Harbor, 1989, 123 p.

SILVA, A.T. Estudo da divergência em acessos de arroz através de marcadores morfológicos e moleculares (RAPD). 1999. p. 27-41. Tese (Doutorado em Fitotecnia) - Universidade Federal de Lavras, Lavras.

SILVA, H.T.; FONSECA, J.R.; FREIRE, M.S.; FREIRE, A.B. Enriquecimento da variabilidade genética de arroz e feijão. In: SIMPÓSIO DE RECURSOS GENÉTICOS PARA A AMÉRICA
LATINA E CARIBE - SIRGEALC, III, 2001, Londrina. Anais... Londrina: IAPAR, 2001, p. 177-179.

SINGH, A.K.; SINGH, S.B.; SINGH, S.M. Genetic divergence in scented and fine genotypes of rice (Oryza sativa L.). Journal of Agricultural Research, Washington, v.17, n.2, p.163-166, 1996.

SOUZA, E.; SOUVELIS, M.E. Inheritance and frequency of a nullallele for diaphoreses activity in North American oat cultivars. Journal of Hereditary, Baltimore, v. 80, n. 2, p.501503, 1989.

SOUZA, S.R.; STARK, E.M.L.; FERNANDES, M.S. Nitrogen remobilization during the reproductive period in two rice varieties. Journal of Plant Nutrition, New York, v.21, n.10, p.2040-2063, 1998.

TEDESCO, J.M.; GIANELLO, C.; BISSANI, C.A.; BOHNEN, H.; VOLKSWEISS,S.J. Análises de solo, plantas e outros materiais. 2.ed. Porto Alegre: UFRGS, 1995. 174 p.

WAUGH, R.; BAIRD, E.; POWELL, W. The use of RAPD markers for the detection of gene ingression in potato. Plant Cell Report. New York, v. 11, n. 5, p. 466-69, 1992.

WILLIANS, J.G.K.; KUBELIK; A.R.; LIVAK, K.J.; RAFALSKI, J.A; TINGEY, S.V. DNA polymorphisms amplified by arbitrary primers are useful a genetic marker. Nucleic Acids Research, Oxford, v.18, p.6531-6355. 1990. 